\title{
SEJARAH PERKEMBANGAN KONSTITUSIONALISME DUNIA DAN INDONESIA (TINJAUAN PERBANDINGAN)
}

\author{
Oleh : Wawan Rosmawan, S.H., C.L.A*)
}

\begin{abstract}
ABSTRAK
Konsep negara hukum yang konstitusional dianggap sebagai konsep universal. negara hukum menurut konsep Eropa Kontinental dinamakan Rechsstaat. Secara Embrionik, gagasan negara hukum telah dikemukakan oleh Plato, ketika la mengitroduksi Konsep Nomoi, sebagai karya tulisnya yang ketiga. Bahwa konstitusionalisme demokrasi nasional, sekuno apapun asal usulnya, tetap merupakan suatu tahapan eksperimental. jika ingin bertahan dalam kompetisi dengan tipe pemerintahan yang lebih revolusioner, paham ini harus bersedia terus menerus beradaptasi dengan kondisi masyarakat modern yang selalu berubah ubah. Tujuan dasar konstitusi politik adalah sama dimanapun dia berada yaitu melindungi kemajuan dan pedamaian sosial, mengamankan hak-hak individu, dan memajukan kesejahteraan nasional. empat kali amanden terhadap UUD 1945 merupakan bukti nyata bahwa Konstitusi negara Indonesia terus menerus beradaptasi dengan kondisi masyarakat yang selalu berubah ubah, yang tentunya proses amandemen UUD 1945 itu bertujuan untuk kemajuan dan pedamaian sosial, mengamankan hak-hak individu, dan memajukan kesejahteraan nasional.
\end{abstract}

Kata Kunci : Konstitusionalisme, Konstitusi

\begin{abstract}
The concept of state constitutional law is regarded as a universal concept. according to state law called the Continental European concept Rechsstaat. In embryonic, the idea of a state of law has been put forward by Plato, when he mengitroduksi Nomoi concept, as his writings were third. That the national democratic constitutionalism, as old as any origins, remains an experimental stage. if it is to survive in competition with the type of government that is revolutionary, this understanding must be willing to continually adapt to the ever-changing modern society change. The basic purpose of the political constitution is the same wherever he is, namely protecting social progress and any peace, securing individual rights, and promote national welfare. amanden four times against 1945 is clear evidence that the country's Constitution Indonesia continuously adapt to ever-changing conditions of society change, which is of course the 1945 amendment was aimed at social progress and any peace, securing individual rights, and promote national welfare.
\end{abstract}

Keywords: Constitutionalism, Constitution

*) Alumni FH Unigal Angkatan 2011, Advokat. 
PENDAHULUAN

Muculnya negara kostitusional pada dasarnya merupakan suatu proses sejarah, konsep negara hukum yang konstitusional dianggap sebagai konsep universal. negara hukum menurut konsep Eropa Kontinental dinamakan Rechsstaat. Secara Embrionik, gagasan negara hukum telah dikemukakan oleh Plato, ketika la mengitroduksi Konsep Nomoi, sebagai karya tulisnya yang ketiga.

Dalam Nomoi Plato mengemukakan bahwa penyelenggaraan negara yang baik ialah yang didasarkan pada pengaturan (hukum) yang baik (Tahir Azhari, 1992 :

66), gagasan Plato tentang negara hukum ini semakin tegas ketika didukung oleh muridnya Aristoteles. Dalam bukunya Politea, Aristoteles mengemukakan suatu negara yang baik ialah negara yang diperintah dengan konstitusi dan berkedaulatan hukum.

Menurut Aristoteles ada tiga unsur pemerintahan yang berkonstitusi pertama pemerintahan dilaksanakan untuk kepentingan umum, kedua pemerintahan dilaksanakan menurut hukum yang berdasarkan pada ketentuan-ketentuan umum bukan pada hukum yang dibuat secara sewenangwenang yang mengenyampingkan konvensi dan konstitusi, ketiga pemerintahan berkonstitusi berarti pemerintahan dilaksanakan atas kehendak rakyat, bukan berupa paksaan-paksaan yang dilaksanakan pemerintahan. (Ridwan HR, 2006 : 2).

Dalam kaitannya dengan konstitusi, Aristoteles mengatakan bahwa konstitusi merupakan penyusunan jabatan dalam suatu negara dan menentukan apa yang dimaksudkan dengan badan pemerintahan dan apa akhir dari setiap masyarakat, selain itu konstitusi merupakan aturan-aturan dan penguasa harus mengatur negara menurut aturanaturan negara tersebut (Azhari, 1995 : 20-21).

\section{LATAR BELAKANG}

Bahwa konstitusionalisme demokrasi nasional, sekuno apapun asal usulnya, tetap merupakan suatu tahapan eksperimental. jika ingin bertahan dalam kompetisi dengan tipe pemerintahan yang lebih revolusioner, paham ini harus bersedia terus menerus beradaptasi dengan kondisi masyarakat modern yang selalu berubah ubah. Tujuan dasar konstitusi politik adalah sama dimanapun dia berada yaitu melindungi kemajuan dan pedamaian sosial, mengamankan hak-hak individu, dan memajukan kesejahteraan nasional. (C.F. Strong; 2004 : 75). 
Apa yang diungkapkan oleh C.F. Strong itu nampaknya seleras dengan apa yang terjadi di Negara Kesatuan Republik Indonesia, dimana sejak awal kemerdekaan tahun 1945 hingga sekarang ini, NKRI telah mengalami banyak perubahan dalam Konstitusinya, empat kali amanden terhadap UUD 1945 merupakan bukti nyata bahwa Konstitusi negara Indonesia terus menerus beradaptasi dengan kondisi masyarakat yang selalu berubah ubah, yang tentunya proses amandemen UUD 1945 itu bertujuan untuk kemajuan dan pedamaian sosial, mengamankan hakhak individu, dan memajukan kesejahteraan nasional.

Berangkat dari latar belakang itulah makalah ini disusun untuk mengetahui apakah ada kaitan dan pengaruh sejarah perjalanan pemikiran mengenai konstitusi yang berada di berbagai belahan dunia terhadap perubahan konstitusi di Negara Kesatuan Republik Indonesia. Sebab konstitusinalisme modern berkembang dari dua dasar utama, yaitu nasionalisme dan demokrasi representatif, meskipun demikian, nasionalisme termasuk perkembangan yang relatif baru karena negara konstitusional tidak bisa berkembang di zaman dunia kuno. (C.F. Strong; 2004 : 75)

\section{IDENTIFIKASI DAN PEMBATASAN} MASALAH

Makalah ini yang mengambil tema tentang sejarah perkembangan Konstitusi Dunia dan Pengaruhnya terhadap perubahan konstitusi di Indonesia ini membatasi pembahasannya pada hal-hal berikut ini ;

1. Konstitusionalisme Yunani

2. Konstitusi Romawi

3. Konstitusionalisme di Abad Pertengahan

4. Konstitusionalisme di Inggris

5. Konstitusionalisme Nasional Pada Pertengahan Kedua Abad ke 19

6. Konstitusionalisme dan Perang Dunia I

7. Konstitusi Indonesia dari Masa ke Masa

Sedangkan identifikasi masalah yang dikemukakan dalam peyusunan makalah ini adalah membahas tentang riwayat perkembangan konstitusi dan sejarah gagasan-gagasan politik yang mendorong dan mempengaruhi perkembangan konstitusi di Negara Indonesia.

\section{PEMBAHASAN}

\section{KONSTITUSIONALISME YUNANI}

Bagi Bangsa Yunani, negara merupakan seluruh pola pergaulannya, sebuah kota tempat terpenuhinya semua kebutuhan secara materi dan 
spiritual (C.F Strong; 1996 : 24). Salah filusuf Yunani, Aristoteles memahami istilah negara yang digunakannya sebagai segala sesuatu yang diartikan sekarang sebagai istilah negara, masyarakat, organisasi, eknomi, bahkan agama. Bahkan Bagi Aristoteles negara bukanlah ikatan spiritual, bukan alat kelengkapan pemerintahan belaka.

Keberadaan Negara, kata Aristoteles, tidak semata-mata untuk memungkinkan adanya kehidupan, tetapi untuk membuat kehidupan bisa berjalan lebih baik (C.F Strong; 1996 : 24). Bagi Filsuf-filsuf Yunani seperti Plato dan Aristoteles, tidak ada pertentangan antara individu dengan negara. sebaliknya negara adalah satusatuya cara bagi individu untuk mewujudkan tujuan-tujuan terbainya dan manusia bukanlah seorang manusia yang baik kecuali jika dia juga seorang warga negara yang baik.

konstitusi ideal baik menurut plato maupun aristoteles menekankan pentingnya pendidikan politik, sebab melalui warga negara yang terdidik, negara dapat dilindungi dari timbulnya anari, menurut pemikiran Plato dan Aristoteles, anarki merupakan akibat dari ketidak kontrolnya perkembangan demokrasi (C.F Strong; 1996 : 24). Solusi Plato seperti dijelaskan dalam karyanya Republic, terletak pada suatu aristokrasi cendikiawan politik, suatu badan pelindung yang memenuhi syarat untuk memerintah dengan sistem pendidikan kaku yang seharusnya memimpin terciptanya negara ideal. walaupun konstitusionalisme politik Yunani telah berakhir, idealisme politik mereka masih tertinggal dan sulit untuk memperkirakan apa jadinya pemerintahan politik masa kini tanpa adanya inspirasi yang diperroleh dari contoh klasik ini.

\section{KONSTITUSI ROMAWI}

Pentingnya Romawi dalam sejarah konstitusionalisme terletak pada fakta bahwa peranan konstitusinya dalam dunia kuno dapat diperbandingkan dengan peranan konstitusi dalam dunia modern.

Awalnya, konstiitusi romawi merupakan sebua instrumen pemerintahan yang sangat mantap, meskipun tidak ditemukan dalam bentuk tertulis, konstitusi Romawi terdiri dari sekumpulan preseden yang dibawa dalam ingatan seseorang atau tercatat secara tertulis, kumpulan keputusan pengacara, negarawan, kumpulan adat istiadat, kebiasaan, pengertian, dan keyakinan yang berhubungan dengan metode pemerintahan (C.F Strong; 1996 : 24). 
Konstitusi Romawi dimulai sebagai suatu perpaduan harmonis antara elemen-elemen monarki, aristokratis, dan demokratis dan berakir sebagai aristokratis yang tidak bertanggung jawab. walaupun demikian, tidak dapat dilupakan bahwa hal ini pasti terjadi seiring dengan perkembangan kekaisaran Romawi yang wilayahnya sangat luas dengan beraneka ragam suku bangsa dan kepentingan. Kekaisaran seperti ini menuntut adanya suatu instrumen kekuatan yang cepatdn efisien yang hanya dapat dipenuhi oleh suatu kedaulatan absolut disatu tangan (C.F Strong; 1996 : 24).

Pengaruh abadi konstitusionalisme Romawi dapat dilihat pertama hukum Romawi (roman law) berpengaru besar terhadap sejarah hukum eropa kontinental, kedua kecintaan bangsa Romawi akan ketenteraman dan kesatuan sangat kuat sehingga orangorang di abad pertengahan terobsesi dengan gagasan kesatuan politik dunia untuk menghadapi kekuatan disintegrasi (C.F Strong; 1996 : 24).

\section{KONSTITUSIONALISME DI ABAD PERTENGAHAN}

Fenomena Feodalisme pada abad pertengahan mulai berkembang pesat di seluruh Eropa. Feodalisme adalah salah satu konstitusionalisme abad pertengahan karena dalam beberapa taraf tersusun menjadi suatu menjadi suatu bentuk pemerintahan sosial dan politik yang dapat diterima secara umum.

Ciri utamanya adalah pembagian negara menjadi unit-unit kecil. prinsip umum feodalisme adalah "setiap orang harus punya penguasa" (C.F Strong; 1996 : 24). Hal ini semakin menambah hak-hak prerogatif bayangan di dalam kekaisaran di abad pertengahan tanpa menambah hakikatnya. Kejahatan feodalisme terletak pada sedemikian banyaknya kekuasaan yang diberikan pada baron-baron tinggi dan proporsi kekuatan mereka dimasa itu yang tehambat ketika negara kesatuan bangkit. Oleh karena itu raja-raja kuat dari abad pertengahan adalah mereka yang melakukan segala daya dan upaya untuk memusatkan kekuasaan di tangan mereka sendiri dan menyusun suatu kontrol pusat yang merusak supremasi pada baron. Dengan cara ini feodalisme berkembang secara pasi untuk menjembatani jurang pemisah antara chaos pada awal abad pertengahan dan keteraturan di negara modern(C.F Strong; 1996 : 24).

\section{KONSTITUSIONALISME DI INGGRIS}

Menjelang paruh kedua abad pertengahan abad ke-18, Inggris adalah 
sebuah negara konstitusional, walaupun bukan negara demokratis. Selama abad ke-18 Inggris merupakan satu-satunya negara konstitusional di dunia. oleh karena itu, tak pelak lagi sistem konstitusi di inggris telah menjadi contoh bagi perkembangan konstitusional di negara negara lain dewasa ini.

konstitusi di Inggris adalah hasil dari perkembagan konvensi yang berlangsung lambat dan bukan penemuan yang disengaja yang dihasilkan dari sebuah teori. Walaupun perkembagannya bukan merupakan hasil sebuah teori atau banyak teori, konstitusi Inggris telah dijadikan titik tolak pemikiran politik yang mencirikan abad ke-17 dan abad ke-18. Konstitusi Inggris mampu mengadaptasi dirinya dengan kondisi baru dan menambahkan unsur-unsur baru yang dihasilkan oleh konstitusi terdokumentasi yang muncul kemudian pada konstitusi yang sudah ada tanpa mengubahnya secara mendasar (C.F Strong; 1996 : 24).

\section{KONSTITUSIONALISME DAN PERANG DUNIA I}

Menjelang perang dunia I pada tahun 1914, eksperimen konstitusional nasional dalam berbagai bentuk telah dicobakan di setiap negara Eropa dengan pengecualian Rusia. Pada Masa ini Konstitusionalisme tidak hanya terbatas di Eropa, Amerika Serikat dan Dominion (daerah kekuasaan) inggris yang berpemerintahan sendiri, pada masa inipula konstitusionalisme telah menyebar pula ke belahan lain dunia hingga ke tempat-tempat yang jauh, seperti Amerika Selatan, Jepang, dan Bahkan Cina.

Dan Konstitusionalisme pada masa ini selalu dibentuk menurut bentuk lain dari model Inggris yang diadopsi oleh Amerika Serikat, dengan kata lain konstitusionalisme membentuk institusi representatif dan menjadikan bangsa sebagai basis negara (C.F Strong; 1996 : 24).

\section{KONSTITUSI INDONESIA DARI MASA} KE MASA

Sejak proklamasi 17 Agustus 1945, hingga sekarang di Indonesia telah berlaku tiga macam undangundang dasar dalam beberapa periode yaitu ;

a. Periode 18 Agustus 1945-27 Desember 1949.

b. Periode 27 Desember 1949-17 Agustus 1950.

c. Periode 17 Agustus 1950-5 Juli 1959.

d. Periode 5 Juli 1959-Sekarang.

(C.F Strong; 1996 : 24).

Saat Republik Indonesia diproklamasikan pada tanggal 17 
Agustus 1945, negara yang baru ini belum mempunyai undang-undang dasar. baru sehari kemudian pada tanggal 18 Agustus 1945 oleh panitia persiapan kemerdekaan indonesia (PPKI) disahkan Undang-Undang Dasar 1945 sebagai Undang-Undang dasar Republik Indonesia (C.F Strong; 1996 : 86-87).

Undang-undang Dasar Negara Republik Indonesia tahun 1945 sebagaimana terakhir telah diubah pada tahun 1999, 2000, 2001 sampai dengan 2002 merupakan satu kesatuan rangkaian perumusan hukum dasar yang berfungsi sebagai sarana pengendali terhadap penyimpangan dan penyelewengan dalam dinamika perkembangan zaman dan sekaligus sarana pembaharuan masyarakat serta sarana perekayasaan ke arah cita-cita kolektif bangsa (Jimly Asshiddiqie, $2010: 30)$.

Belajar dari kekurangan sistem demokrasi politik dari berbagai belahan dunia yang menjadikan Undang-Undang Dasar sebagai Konstitusi politik, disamping juga berisi dasar-dasar pemikiran mengenai demokrasi ekonomi, dan demokrasi sosial. Oleh karena itu undang-undang dasar ini disebut sebagai konstitusi politik, konstitusi ekonomi, dan sekaligus konstitusi sosial yang mencerminkan cita-cita kolektif bangsa, baik dibidang politik dan ekonomi maupun sosial budaya dengan tetap memeihara tingkat abstraksi perumusannya sebagai hukum dasar (Jimly Asshiddiqie, 2010 : 30-31).

$$
\text { Undang-Undang Dasar } 1945
$$

pertama kali sahkan berlaku sebagai konstitusi negara Indonesia dalam sidang Panitia Persiapan Kemerdekaan Indonesia (PPKI) pada tanggal 18 Agustus 1945, yaitu sehari setelah negara Republik Indonesia diproklamasikan oleh Soekarno dan Mochammad Hatta, namun demikia seteah resmi disahkan pada tanggal 18 Agustus 1945, Undang-Undang Dasar 1945 ini tidak langsung dijadikan referensi dalam setiap pengambilan keputusan kenegaraan dan pemerintahan. Undang-Undang Dasar 1945 hanya pada pokoknya benar-benar dijadikan alat saja untuk sesegera mungkin membentuk negara merdeka bernama Republik Indonesia Pada Awalnya Undang-Undang Dasar 1945 memang dimaksudkan sebagai UndangUndang Dasar sementara yang menurut istilah bung Karno sendiri merupakan revolutie-groundwet atau undangundang dasar kilat, yang memang harus diganti dengan yang baru apabila negara merdeka suah berdiri dan keadaan sudah memungkinkan (Jimly Asshiddiqie, 2010 : 34-35). 
Sebagai Negara yang baru merdeka, masih harus melakukan banyak hal yang tidak sepenuhnya dapat diikat oleh aturan-aturan konstitusional yang ketat, maka UndangUndang Dasar 1945 memang tidak selalu dijadikan referensi. Misalnya menurut ketentuan Undang-Undang Dasar 1945, sistem pemerintahan yang dianut adalah sistem presidensiil, atas dasar itu pada tanggal 2 September 1945 dibentuklah susunan kabinet pertama di bawah tanggung jawab presiden Sekarno, akan tetapi baru dua bulan setelah itu yaitu tepatnya pada tanggal 14 November 1945 pemerintah mengeluarkan maklumat yang berisi perubahan sistem kabinet dari sistem presidensiil ke sistem parlementer.

Pada periode 18 Agustus 1945 sampai dengan 27 Desember 1949, meskipun UUD 1945 secara formal berlaku sebagai konstitusi resmi namun nilainya hanya bersifat nominal, yaitu baru diatas kertas saja. keadaan demikian terus berlangsung sampai tahun 1949 ketika dibentuknya Republik Indonesia Serikat (Jimly Asshiddiqie, 2010 : 36).

Setelah perang dunia kedua berakhir dengan kemenangan di pihak tentara sekutu dan kekalahan di pihak Jepang, maka kepergian bala tentara Jepang dari tanah air Indonesia dimanfaatkan oleh Pemerintahan Belanda untuk kembali menjajah Indonesia.

Sejalan dengan hal itu, tentara Belanda melakukan agresi I pada tahun 1947, dan Agresi II pada tahun 1948 dengan maksud untu kembali menjajah Indonesia. dalam keadaan terdesak dan atas pengaruh perserikatan bangsabangsa (PBB), pada tanggal 23 Agustus 1949 sampai dengan tanggal 2 November 1949 diadakan konferensi meja bundar di den haag belanda.

Konferensi meja bundar di den haag tersebut berhasil menyepakati tiga hal sebagai berikut ;

a. Mendirikan Negara Republik Indonesia Serikat

b. Penyerahan kedaulatan kepada RIS yang berisi tiga hal yaitu (1) piagam penyerahan kedaulatan dari kerajaan belanda kepada pemerintah RIS; (2) Status UNI; dan (3) persetujuan perpindahan.

c. Mendirikan uni antara Republik Indonesia Serikat dengan Kerajaan Belanda.

Naskah Kontitusi RIS disusun bersama dengan delegasi Republik Indonesia dan delegasi BFO ke Konferensi Meja Bundar, rancangan Undang-Undang Dasar itu disepakati oleh kedua belah pihak untuk diberlakukan sebagai undang-undang 
dasar RIS, selanjutnya konstitusi RIS dinyatakan berlaku mulai tanggal 27 Desember 1949. konstitusi RIS yang disusun dalam rangka konferensi meja bundar di den haag pada tahun 1949 itu , pada pokoknya juga dimaksudkan sebagai Undang-Undang Dasar yang bersifat sementara (Jimly Asshiddiqie, 2010 : 37-38).

Bentuk Negara Federal seperti yang dikehendaki dalam konstitusi RIS mengadung banyak nuansa politis karena berkenaan dengan kepentingan Penjajahan Belanda. Bentuk negara federal RIS ini tidak bertahan lama, sampai akhirnya dicapai kata sepakat antara pemerintah Republik Indonesia Serikat dan Pemerintah Republik Indonesia. kesepakatan itu dituangkan dalam satu naskah persetujuan bersama pada tanggal 19 Mei 1950, yang pada intinya menyepakati dibentuknya kembali NKRI sebagai kelanjutan dari negara kesatuan yang diproklamirkan pada tanggal 17 Agustus 1945.

Dalam rangka persiapan kearah itu, untuk keperluan menyiapkan satu naskah undang-undang dasar, dibentuklah panitia untuk menyusun rancangan undang-undang dasar. pada tanggal 12 agustus 1950 rancangan undang-udang dasar itu disahkan oleh komite nasional indonesia pusat, dan pada tanggal 14 Agustus 1950 disahkan oleh Dewan Perwakilan Rakyat dan senat republik indonesia serikat.

Naskah Undang-Undang Dasar ini baru diberlakukan secara resmi pada mulai tanggal 17 agustus 1950 yaitu dengan ditetapkannya undang-undang nomor 7 tahun 1950. Undang-Undang Dasar Sementara 1950 ini bersifat mengganti, sehingga isinya tidak hanya mencerminkan perubahan konstitusi Republik Indonesia Serikat tahun 1949, tetapi menggantikan naskah konstitusi RIS itu dengan naskah baru sama sekali dengan nama Undang-undang dasar sementara tahun 1950.

Seperti halnya konstitusi RIS 1949, Undang-Undang Dasar Sementara 1950 ini juga bersifat sementara, hal ini terlihat jelas dalam rumusan pasal 134 yang mengharuskan konstituante bersama dengan pemerintah menyusun Undang-Undang Dasar Negara Republik Indonesia yang akan menggantikan Undang-Undang Dasar Sementara 1950 itu. Sayangnya majlis konstituante ini tidak atau belum sampai berhasil menyelesaikan tugasnya untuk menyusun undangundang dasar yang baru, sampai akhirnya presiden Soekarno berkesimpulan bahwa konstituante telah gagal.

Atas dasar itulah kemudian presiden Soekarno mengeluarkan dekrit 
presiden tanggal 5 juli 1959 yang memberlakukan kembali UndangUndang Dasar 1945 sebagai UndangUndang Dasar negara Republik Indonesia, dikemudian hari muncul banyak kontroversi mengenai dekrit presiden itu hal ini menyangkut status hukum berlakunya dekrit presiden. Namun terlepas dari kontroversi itu yang jelas sejak Dekrit Presiden 5 Juli 1959 sampai sekarang ini UUD 1945 terus berlaku dan diberlakukan sebagai hukum dasar (Jimly Asshiddiqie, 2010 : 40-41).

\section{KESIMPULAN}

Apa yang dapat diambil kesimpulan mengenai perkembangan sejarah konstitusionalisme di dunia dan pengaruhnya terhadap konstitusi Indonesia?, jawabannya tentu knstitusionalisme tidak dapat dipahami secara utuh jika tidak mengacu pada sejarahnya, setiap masa yang dilalui telah menyumbangkan bagiannya pada sejarah perkembangan konstitusionalisme secara keseluruhannya.

Konstitusionalisme Yunani memberikan inspirasi pada filsafat politik dan selama masa kebangkitan kembali ilmu pengetahuan pada abad ke 15, membuka pikiran umat manusia tentang tujuan-tujuan pemerintahan yang lebih baik. sedangkan konstitusionalisme
Romawi menyumbangkan realitas Hukum dan Cita-cita Kesatuan, dan Feodalisme menjembatani jurang pemisah antara chaos yang menyusul jatuhnya kekaisaran Romawi di barat dengan kebangkitan negara modern.

Konstitusionalisme di Inggris memasukkan kontinuitas kehidupan institusi liberal selama ber abad-abad, sementara di tempat lain institusi liberal telah lenyap atau tidak pernah ada, hal ini berdampak terhadap berkembangnya institusi lain diantara komunitaskomunitas lain di seluruh dunia yang berada di bawah jajahan Inggris dan menyumbangkan pola konstitusi yang digunakan komunitas-komunitas yang baru saja merdeka.

Bahwa konstitusionalisme demokrasi nasional, sekuno apapun asal usulnya, tetap merupakan suatu tahapan eksperimental. jika ingin bertahan dalam kompetisi dengan tipe pemerintahan yang lebih revolusioner, paham ini harus bersedia terus menerus beradaptasi dengan kondisi masyarakat modern yang selalu berubah ubah. Tujuan dasar konstitusi politik adalah sama dimanapun dia berada yaitu melindungi kemajuan dan pedamaian sosial, mengamankan hak-hak individu, dan memajukan kesejahteraan nasional.

Dalam sejarah ketatanegaraan Indonesia merdeka, telah tercatat 
beberapa upaya yang bertalian dengan konstitusi; (a) pembentukan undangundang dasar, (b) penggantian undangundang dasar dan, (c) perubahan dalam arti pembaharuan undang-undang dasar 1945, yang kesemua hal itu sangat dipengaruhi dengan kondisi global dan sejarah perjalanan konstitusionalisme di berbagai belahan dunia.

\section{DAFTAR PUSTAKA}

Asshiddiqie, Jimly, Konstitusi dan Konstitusionalisme Indonesia (Sinar Grafika : 2010).

Azhari, Tahir, Negara Hukum (Jakarta : Bulan Bintang : 1992).

Hermaily Ibrahim, Moh. Kusnardi, Pengantar Hukum Tata Negara Indonesia (Pusat Studi Hukum Tata Negara, Fakultas Hukum Universitas Indonesia : 1988).

H R, Ridwan, Hukum Administrasi Negara (Jakarta ; Rajawali Pers : 2006).

Strong, C.F Konstitusi Konstitusi Politik Modern, Kajian Tentang Sejarah dan Bentuk-Bentuk Konstitusi Dunia (Bandung : Nuansa \& Nusa Media : 2004). , Modern Political Constitution An Introduction to The Comparative Study of Their
History and Existing Form (the English book Society anf Sidgwick \& Jackson Limited London : 1996). 
